DOI 10.14526/2070-4798-2019-14-1-191-197

\title{
Students' vestibular apparatus development using physical exercises from combat sports
}

\author{
Vadim Yu. Ziambetov* \\ Orenburg State University \\ Orenburg, Russia \\ ORCID: 0000-0002-0151-3671, ziambetov@mail.ru*
}

\begin{abstract}
Physical culture and sport specialists always improve physical-sports activity, directed toward vestibular apparatus and movements coordination development. This direction importance and urgency in sports education nowadays and insufficient attention paid to it in practice, condition the relevance of this article. Combat sports are very popular among modern students, as they correspond with their needs and modern tendencies in youth sphere. Materials. This article considers the ways and means of vestibular apparatus development effectiveness increase in sports education among students of higher educational establishments. We created the complex of exercises taken from combat sports. This complex is directed toward movements coordination development. Research methods. Information sources analysis and summarizing, pedagogical experiment, testing, statistical data handling. Results. The initial results showed a low level of students' vestibular sensory system and coordinating abilities development. The complex of physical exercises use from combat sports provided symptoms decrease of vestibular sensory system stimulation during body position change in space in terms of the support. Coordinating skills and balance indices increased. Conclusion. The research showed that nowadays not much attention is paid to students' vestibular apparatus and coordination of movements development during educational-upbringing work in the sphere of physical culture. Our research results will help to address any gaps in sports education of students.
\end{abstract}

Keywords: vestibular apparatus, physical exercises, combat sports, students, coordination of movements, balance, sensory system.

For citation: Vadim Yu. Ziambetov*. Students' vestibular apparatus development using physical exercises from combat sports. The Russian Journal of Physical Education and Sports. 2019; 14(1): 163-168. DOI 10.14526/2070-4798-2019-14-1-191-197

The question of body balance was always important in research works in the sphere of physical culture and sport $[1,7,8]$. Nowadays new objectives are set in vestibular-motor, vestibular-vegetative, vestibular-sensory reactions study, the control over which will help to influence the system of athletes' physical readiness with a simultaneous increase of coordinating physical exercises characteristics and the level of traumatism decrease.

During recent years in physical-sports activity theory and practice great interest is paid to the problem of vestibular analyzer functional abilities increase as the system, which is important for the athlete's orientation in space and highly-coordinating motor actions fulfillment $[2,9,10,19,20]$.
Nowadays there is sufficient number of scientific information in sport and physical culture theory. It concerns combat sports influence on somatic and vegetative systems of an organism and the opportunities of this information use for training process optimization. According to V.A. Kislyakov (1975), V.I. Orlov (1976), V.N. Boloban (1990), vestibular sensory system plays an important role in movements control and in case of airborne state or in case of complicated conditions this sensory system is the leading one. Later the works of A.S. Rovnyi (2001), N.V. Lyulina (2008) broadened the notion of statokinetic constancy and corrected the structure of physical culture organizational support by means of vestibular apparatus steadiness increase $[11,12,13,14]$. 
Vestibular analyzer together with musclearticular, skin and visual analyzers provides body balance, accurate coordination and movement analysis $[16,17,18]$.

As a rule, vestibular analyzer stability increases with physical readiness increase. The level of competitive achievements in many sports is closely connected with the level of vestibular analyzer stability $[3,15,21,22]$.

The aim of the article is to study the influence of vestibular sensory system steadiness on students' physical abilities during coordination development exercises use from combat sports during physical culturelessons at a higher educational establishment.

In accordance with the set aim, the following objectives were considered:

1) the dynamics revelation of vestibular reflexes changes during students' sports education using coordinating skills exercises from combat sports;

2) symptoms of vestibular apparatus stimulation decrease (giddiness, sickness, retch and others) during physical exercises fulfillment with body position change;

3) the effectiveness of coordinating skills development increase among students during physical culture lessons.

\section{Materials and Research Methods}

The subject of the research is presented by special exercises from combat sports in order to increase vestibular sensory system steadiness.

The object of the research is presented by male students of Orenburg State University. 100 people took part in the research. They had equal physical readiness level. The experimental group (EG) included 50 people, control group (CG) included 50 people.

\section{Research Methods}

Information sources analysis and the method of expert analysis, statistic observation, questioning, physiological steadiness tests in Romberg positions, flank and straight line walking tests.

\section{Results and Discussion}

CG students had physical culture lessons 164 which had no emphasis on vestibular sensory system development.

In EG lessons were held according to the created methodology. It included a complex of exercises from combat sports, directed toward vestibular analyzer development.

Vestibular system function was considered in two aspects: as the organ of balance and body orientation in space and as the organ of metabolic processes regulation for an optimal energy regimen of an active movement during the given time period. Great attention was paid to the ability of vestibular apparatus to restore own functions after stimulation caused by specific exercises from combat sports [4].

The complex of exercises was created on the basis of the hypothesis, that even insignificant angular and rectilinear acceleration well trained vestibular analyzer, sending information about movement to the brain, helps to avoid vegetative disorders and helps to fulfill motor objective in the set spatiotemporal parameters.

In this case the following things are important: safety provision during the lessons and the ability of a teacher to motivate students to fulfill these difficult for coordination, not easy, but useful physical exercises $[5,6]$.

In our opinion, the most effective complex for vestibular sensory system training (and control) included the following exercises:

1 - Sideway rolls in quick tempo 7 times to the right, to the left and hoop rotation (walking with legs strikes imitation along the line).

2 - Rolls forward- 10 times slowly, 2 times quickly, after 12 seconds break- 5 rolls backward slowly and winders along the line $18 \mathrm{~m}$.

3 - Pole walking (broom handle) for 10 meters distance, with hands position change on command (or different strikes imitation with hand).

4 - Candle stand-6o seconds, spring-board (wrestling)-15 seconds, then stand up quickly on one leg hands aside ("lastochka", "swallow").

5 - Circular motions to the right and to the left eyes closed in a quick tempo-10-12 times, basketball ball throwing in the basket (or "shadow boxing").

6 - A jump turn to the right and to the left 12 times with $90^{\circ}, 180^{\circ}$ and $360^{\circ}$, with ball throwing 
into the target.

The research was held within 4 stages, starting from the beginning of the academic year with further period division (duration-one week). The complex of exercises was introduced at the second stage. The estimation criteria for the fulfilled

Table 1 - The results of the exercises fulfillment at different stages

\begin{tabular}{|c|c|c|c|c|c|c|c|c|c|c|}
\hline \multirow{2}{*}{$\begin{array}{c}\text { Numbers } \\
\text { of exercises }\end{array}$} & \multicolumn{9}{|c|}{ EG } & \multicolumn{5}{|c|}{ CG } \\
\cline { 2 - 11 } & I & II & III & IV & Total & I & II & III & IV & total \\
\hline Exercise 1 & 134 & 167 & 183 & 204 & 688 & 153 & 162 & 148 & 160 & 623 \\
\hline Exercise 2 & 94 & 102 & 140 & 154 & 490 & 87 & 91 & 83 & 79 & 340 \\
\hline Exercise 3 & 143 & 148 & 179 & 198 & 568 & 139 & 140 & 138 & 153 & 570 \\
\hline Exercise 4 & 152 & 171 & 195 & 213 & 731 & 160 & 164 & 158 & 161 & 643 \\
\hline Exercise 5 & 86 & 112 & 143 & 167 & 508 & 81 & 73 & 75 & 91 & 320 \\
\hline Exercise 6 & 159 & 151 & 177 & 199 & 686 & 170 & 165 & 173 & 171 & 679 \\
\hline Total : & 768 & 851 & 1017 & 1135 & 3771 & 790 & 795 & 775 & 815 & 3175 \\
\hline
\end{tabular}

The picture presents the dynamics of indices according to the control exercises in groups. It shows that the indices increase in EG to the end of the experiment was 367 points in total, in CG only exercises were created and each exercise was estimated according to 5-point system. The points received by each student for the exercises fulfillment in a group were summarized. The research results are presented in table 1.
25 points. Some indices increase in the CG we can explain by the developing character of physical culture lessons and tests themselves.

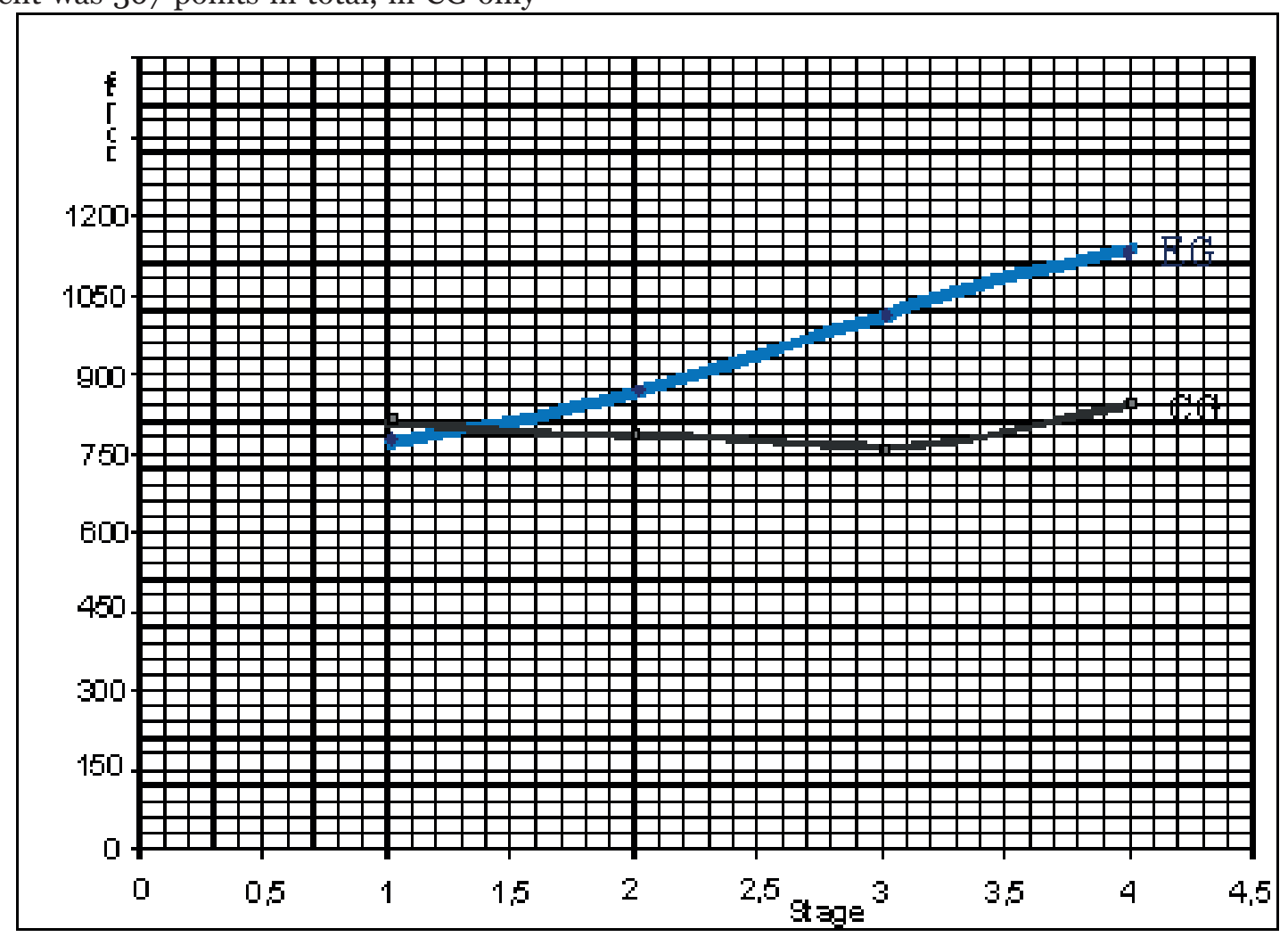

Picture - The dynamics of indices change in the experimental and control groups 
As the methodologies of vestibular reflexes study, which reflect the function of balance and pose and provide accurate statistical objectives fulfillment, Romberg test was used. This test consists of 4 positions and also walking along the straight line and flank walk. Received during four stages results helped to reveal positive changes in technical indices of the experimental group respondents (table 2).

Table 2 - Romberg test

\begin{tabular}{|c|c|c|c|c|c|c|c|c|}
\hline \multirow{2}{*}{ Number of position } & \multicolumn{4}{|c|}{ EG } & \multicolumn{4}{|c|}{ CG } \\
\cline { 2 - 9 } & I & II & III & IV & I & II & III & IV \\
\hline I position, s & 12 & 15 & 20 & 22 & 12 & 13 & 15 & 18 \\
\hline II position, s & 11 & 17 & 22 & 23 & 10 & 12 & 18 & 18 \\
\hline III position, s & 16 & 25 & 30 & 33 & 15 & 26 & 28 & 28 \\
\hline IV position, s & 10 & 18 & 22 & 25 & 10 & 15 & 16 & 17 \\
\hline
\end{tabular}

The first position: hands forward stand, supporting leg.

fingers are straight and apart.

The fourth position: "lastochka" (swallow)

The second position: the initial position is position. like in the first position, but the feet are placed along the line and the toe of one foot touches the heel of the other foot.

The third position: one leg stand, the

The respondent stands with his eyes closed in each position during 30 seconds. The table presents the average time indices in a group.

The results of straight and flank lines test other leg is bent and touches the knee-cap of the are presented in table 3 .

Table 3 - The results of straight and flank lines test

\begin{tabular}{|c|c|c|c|c|c|c|c|c|c|}
\hline \multicolumn{2}{|c|}{ Walk } & \multicolumn{4}{|c|}{ EG } & \multicolumn{4}{c|}{ IV } \\
\cline { 2 - 11 } & I & II & III & IV & I & II & III & IV \\
\hline \multirow{2}{*}{$\begin{array}{c}\text { Along the } \\
\text { straight line }\end{array}$} & $\begin{array}{c}\text { The amount with vestibular analyzer } \\
\text { disorder }\end{array}$ & 4 & 4 & 40 & 40 & 4 & 4 & 44 & 43 \\
\cline { 2 - 13 } & The amount with cerebellum disorder & 1 & 1 & 9 & 8 & 9 & 9 & 8 & 8 \\
\hline \multirow{2}{*}{ Flank } & $\begin{array}{c}\text { The amount with vestibular analyzer } \\
\text { disorder }\end{array}$ & 4 & 4 & 38 & 36 & 4 & 3 & 39 & 38 \\
\cline { 2 - 12 } & The amount with cerebellum disorder & 5 & 6 & 4 & 4 & 6 & 6 & 5 & 5 \\
\hline
\end{tabular}

Vestibular analyzer estimation in straight walking included the following. The student makes 5 steps with his eyes closed along the straight line forward and not turning makes 5 steps back. Inaccuracy of motor actions fulfillment shows the low level of coordinating abilities.

During flank walking estimation a student makes 5 chasse steps to the right, then 5 chasse steps to the left.

The received results are characterized by vestibular system steadiness increase, in particular vestibular sensory and vestibular cerebellar reactions. It is characterized by positive dynamics of training in body position preservation during movements and giddiness resistance. These results show the effectiveness of training lessons with physical exercises use from combat sports in order to develop vestibular apparatus. In time course students stop complaining of sickness and giddiness after the exercises fulfillment.

\section{Conclusion}

Thus, the held research helps to make conclusion that the specific physical exercises use from combat sports increases students' vestibular sensory system steadiness, develops coordination and accuracy of movements, the ability to keep the balance in terms of vestibular apparatus stimulation. The complexes of special exercises use from combat 
sports, directed toward vestibular sensory system training, helped to decrease the number of somatic reactions caused by this system stimulation. This aspect has great applied importance in a student's physical culture development as the specialists and increases the role of physical culture in the sphere of higher education [6].

\section{References}

1. Golova E.V. Means of corrective gymnastics during physical culture lessons at a higher educational establishment for students' vestibular apparatus activity prophylaxis. Sovremennye issledovaniya: materialy Mezhdunarodnoj nauchnoprakticheskoj konferencii [Modern research: materials of the International scientific-practical conference]. Neftekamsk. 2017; 884-889 (In Russ.).

2. Chertikhina N.A., Shevchuk N.A. The search for non-traditional means of vestibular resistance development among young female gymnasts. Fizicheskoe vospitanie i sportivnaya trenirovka. 2012; 1(3): 34-38 (In Russ.).

3. Vasyukevich A.A. About the question of statokinetic resistance training in sports aerobics. Sport I turizm: administrirovanie i razvitie: materialy Mezdunarodnoj nauchno-prakticheskoj konferencii, 13-15 oktyabrya 2017 [Sport and Tourism: Administration and development: materials of the International scientific-practical conference, October, 13-15, 2017]. Kaliningrad 2017; 21-29 (In Russ.).

4. Ziambetov V.Yu. Samooborona, ee pravovye osnovy I metodika ee primeneniya [Selfdefense, its fundamental legal principles and the methodology of its use]. Orenburg: LLC Publishing Complex "Universitet". 2016: 105.

5. Zub I.V., Korol F.V. Statokinetic resistance development as one of the aspects of professionally applied training of the future fleet specialist. Strategicheskie napravleniya reformirovaniya buzovskoi sistemy fizicheskoi kultury: materialy $\mathrm{V}$ Vserossijskoj nauchno-prakticheskoj konferencii, 18 aprelya 2018g. [Strategic directions of reforming the basic system of physical culture: materials of the Vth All-Russian scientific-practical conference, April 18, 2018]. Saint-Petersburg. 2018: 346-349 (In Russ.).
6. Nikolas M. Belokrylov, Ludmila V. Sharova, Alexey V. Shepalov, Svetlana V. Annenkova. Training Simulator for Correct Walking Formation and Vestibular Apparatus Training. Pedagogikopsihologicheskie I medico-biologicheskie problemy fizicheskoj kul'tury I sporta= Pedagogicopshycological and medico-biological problems of physical culture and sports. 2016; 11(4): 152-162. DOI: 10.14526/01_1111_168 (In Russ., In Engl.).

7. Khudyakov G.G., Kostenok P.I., Beloedov A.V. Sports training development of young basketball players owing to functional abilities increase of vestibular apparatus. Fundamentalnye issledovaniya. 2014; 1: 79-81 (In Russ.).

8. Chertikhina N.A., Shevchuk N.A. Methodology of vestibular resistance development among young female gymnasts. Fizicheskoe vospitanie i sportivnaya trenirovka. 2013; 1(5): 3438 (In Russ.).

9. Shevchuk N.A., Chertikhina N.A. Training simulators use in rhythmic gymnastics for vestibular resistance increase. Kul'tura fizicheskaya I zdorov'e. 2011; 4: 79-81 (In Russ.).

10. Khabirova Z.Z., Bekmansurov R.K. Complex of vestibular gymnastics. Prioritetnye nauchnye napravleniya: ot teorii $\mathrm{k}$ praktike: materialy XXXIX Mezhdunarodnoj nauchnoprakticheskoj konferencii, 30 maya 2017 [Priority scientific directions: from theory to practice: materials of the XXXIX International scientificpractical conference, May, 30, 2017]. Novosibirsk. 2017: 57-61 (In Russ.).

11. Frolova S.V. Variants of games and exercises with sports balance cushions. Fizicheskaya kultura, sport i zdorove: sovremennoe sostoyanie I puti razvitiya: materialy Vserossijskoj nauchnoprakticheskoj konferencii [Physical culture, sport and health: current state and ways of development: materials of All-Russian scientific-practical conference, April 21, 2017]. Murmansk. 2017: 5-15 (In Russ.).

12. Belyakov A.A., Dakhin A.N. The basis of methodology of vestibular resistance control. Fizicheskaya kultura I sport v structure professionalnogo obrazovaniya: retrospektiva, real'nost' I buduchee: sbornik materialov mezhvedomstvennogo kruglogo stola [Physical 
education and sport in vocational education: a retrospective, the reality and the future: collection of materials of interdepartmental round table discussion]. Irkutsk. 2017: 266-270 (In Russ.).

13. Drobot V. E., Kosko V.E., Kosova N.P.

Vestibular apparatus influence on the accuracy of movements. Nauchnye Trudy Dalnevostochnogo gosudarstvennogo tekhnicheskogo rybokhozyaystvennogo universiteta. 2009; 21: 147148 (In Russ.).

14. Isroilov S. S., Khusainova D.T. The importance of functions development of body balance keeping during tennis playing. Obrazovanie i ped. nauki $\mathrm{v}$ XXI veke: aktualnye voprosy, dostizheniyaiinnovatsii:materialy Mezhdunarodnoj nauchno-prakticheskoj konferencii, 25 janvarya 2017 [Education and pedagogical science in the XXI century: topical issues, achievements and innovations: materials of the International Scientific-practical conference, January, 25, 2017]. Penza. 2017: 126-129 (In Russ.).

15. Pashchenko L.G., Khazieva R.F., Kalashnikov A.A. Coordinating abilities study among those, who go in for bouncing. Kultura, nauka, obrazovanie: problemy I perspektivy: materialy VI Mezhdunarodnoj nauchno-prakticheskoj konferencii [Culture, science, education: problems and prospects: materials of the VI International scientific-practical conference, February, 13-15, 233.

2017]. Nizhnevartovsk. 2017: 347-349 (In Russ.).

Submitted: 09.01.2019

\section{Author's information:}

Vadim Yu. Ziambetov* - Candidate of Pedagogics, Associate Professor, Orenburg State University, 46oo18, Russia, Orenburg, Pobeda ave., House 13, e-mail: ziambetov@mail.ru*

16. Brandt Th., Bartenstein P., Janck A., Dictcrich M. Reciprocal inhibitory visual vestibular interaction: Visual motion stimulation deactivates the parieto-insular vestibular cortex. 1998; 121: 1749-1758.

17. Brctz K., Lee C., Kcskinen K.L., Komi P., Mcro A. Static balance and motor coordination in elderly. Ann. Rev. Physiology. 1998; 75: 128-129.

18. Johnston R.B., Howard M.E., Cawlcy P.W, Losse G.M. Effect of lower extremity muscular fatigue on motor control performance. J. Medicine and Science in Sports and exercise. 1998; 30(12): 17031707.

19. Kallinen M., Marklcu A. Aging Physical activity and Sports injuries. An overview of common injuries in the elderly. Sports Medicine. 1995; 20(1): 41-52.

20. Zlatev K. Research of stability of equilibrium in an early selection in a sporting gymnastics. J. Questions of physical culture. 1984; 1: 32-39.

21. Vardar S.A., Tezel S., Ozturk L., Kaya O. The relationship between body composition and anaerobic performance of elite young wrestlers. Journal of Sports Science and Medicine. 2007; 6(CSSI): 34-38.

22. Yoon J. Physiological profiles of elite senior wrestlers. Sports Medicine. 2002; 32: 225- 